\title{
DAŽNIAUSI APSINUODIJIMAI VAIKŲ AMŽIUJE
}

\author{
Dovydas Bartkus' ${ }^{1}$, Rugilè Benešiūnaite்1, Lina Jankauskaitè2 \\ ${ }^{1}$ Lietuvos sveikatos mokslu universiteto Medicinos akademija, \\ ${ }^{2}$ Lietuvos sveikatos mokslu universiteto Vaiku ligu klinika, Lietuvos sveikatos mokslu universiteto \\ Kauno klinikos, Vaiku ligu klinika
}

Raktažodžiai: vaikai, apsinuodijimai, intoksikacijos, epidemiologija.

\section{Santrauka}

Tyrimo tikslas - apžvelgti ir išanalizuoti mokslinèje literatūroje pateikiamą vaikų apsinuodijimų epidemiologiją - dažniausius toksinus, apsinuodijimų priežastis, jų baigtị. Šioje apžvalgoje susisteminti viso teksto straipsniai. Remiantis jų rezultatais, galime teigti, jog jaunesniems nei 12 metų vaikams būdingi netyčiniai apsinuodijimai buitinėmis cheminėmis medžiagomis. Vaistais apsinuodijama retai. Vyresniems nei 12 metų būdingi tyčiniai apsinuodijimai laisvalaikio leidimo metu, suicidiniais tikslais, dažniausiai apsinuodijama etanoliu ir psichotropinemis medžiagomis. Didžiajai daliai pacientų, patekusiai ị vaikų skubiosios pagalbos skyrių, taikomas nespecifinis gydymas - aktyvinta anglis, skrandžio plovimas.

\section{Ivadas}

Kasmet pasaulyje milijonai vaikų apsinuodija ịvairiomis medžiagomis. Šis ūmus sveikatos sutrikimas savo dažniu konkuruoja su sužalojimais eismo ịvykiuose, nudegimais bei traumomis [1]. Lietuvoje $2012-2017$ metu duomenimis vidutinis apsinuodijimų rodiklis buvo 62,86 atvejai 10000 vaikų iki 18 metų. Daugiausia apsinuodijimų buvo užregistruota $<4 \mathrm{~m}$. ir 15-18 m. amžiaus grupèse [2]. Nors pasaulyje aktyviai taikomos prevencinès apsinuodijimų programos, literatūros duomenimis, jų efektyvumas neduoda norimų rezultatų. Vis dar parduodami netinkamai supakuoti namų apyvokos produktai (ryškios spalvos, kvapai), tevai namuose juos laiko lengvai pasiekiamose vietose, o apsinuodijus turi mažai žinių, kaip teisingai suteikti pirmają pagalbą. Šios problemos sprendimui įtakos turi ir mažo vaiko nesugebejjimas pasakyti ką suvalgè, baimè būti nubaustam, o dažnas paauglys linkęs slèpti informaciją apie su draugais vartojamas medžiagas ir jų kiekius [3]. Šiame straipsnyje siekiama apibendrinti naujausios mokslinès literatūros duomenis apie apsinuodijimus vaikų amžiuje ir išskirti dažniausias apsinuodijimo priežastis (tyčinis, netyčinis), atsižvelgiant ị amžiaus grupes.

Tyrimo tikslas - pristatyti dažniausias apsinuodijimų priežastis vaikų populiacijoje.

\section{Tyrimo medžiaga ir metodai}

Atlikta sisteminė vaikų apsinuodijimų mokslinès literatūros apžvalga ir analizè. Duomenų paieškai pasirinktos PubMed, Google Scholar ir UpToDate duomenų bazès. Visatekstès, išleistos anglų kalba, ne senesnès nei pastarujų dešimties metų publikacijos atrinktos pagal šiuos kriterijus: i studiją ítraukti 0-18 m. pacientai, pateiktos visos medžiagos ar medžiagų grupès, kuriomis pacientai apsinuodijo, itraukti atsitiktiniai ar tyčiniai apsinuodijimai. Iš viso analizès kriterijus atitiko 11 publikacijų.

\section{Tyrimo rezultatai}

Itrauktos studijos apėmè 7405 vaikų apsinuodijimo atvejus iš viso pasaulio, dèl kurių buvo kreiptasi ị sveikatos priežiūros įstaigas. Intoksikacijos sudarè nuo 0,23 iki 2,3 proc. viso pacientų srauto vaikų skubiosios pagalbos skyriuose (VSPS). Analizuotuose straipsniuose intoksikacijų atvejai pagal lyti svyruoja nuo 29,4 iki 55,6 proc. berniukams ir nuo 44,4 iki 70,5 proc. mergaitèms. Tarptautinès studijos, apėmusios 105 VSPS centrus iš viso pasaulio, duomenimis, mergaičių apsinuodijimai dažnesni Šiaurès Amerikos, Rytų ir Pietryčių Azijos, Australijos ir Okeanijos regionuose. Kituose regionuose (Europoje, Vakarų Azijoje) dažniau apsinuodija berniukai [4]. Sugrupavus pediatrinius pacientus ị skirtingus amžiaus laikotarpius, stebimos išskirtinai kiekvienai amžiaus grupei būdingos apsinuodijimų aplinkybès (1 lentelè) [1, 5-11].

Studijos, itraukusios nuo 0 iki $18 \mathrm{~m}$. pacientus nustatè, jog stebimas bimodalinis intoksikacijų pasiskirstymas pagal pacientų amžių. Pirmasis intoksikacijų atvejų pikas stebimas ikimokyklinio amžiaus vaikams (0-5 metai). Šiai amžiaus grupei būdingi netyčiniai apsinuodijimai įvairiomis namuose rastomis medžiagomis. Tokio amžiaus vaikus auginančios šeimos ị VSPS dèl mergaičių apsinuodijimo atvyksta taip 
pat dažnai, kaip ir dẻl berniukų [5]. Augantis vaikas linkęs tyrinèti supančią aplinką rankomis ir burna, todèl lengvai pasiekiami, patraukliai ipakuoti ir maloniai kvepiantys namų apyvokos produktai, kosmetikos priemonès, vaistai ir kitos medžiagos tampa vizito į VSPS priežastimi. Nors šio amžiaus vaikai jaučia sąvokų ,galima“ ir ,negalima“ skirtumą, jie neturi susiformavusio atliekamų veiksmų pasekmių suvokimo. Prie to prisideda ir apsinuodijimų prevencijos stygius namuose. Neretai šio amžiaus vaikams apsinuodijimo riziką didina tėvų (globėjų) vaiko fizinių galimybių pasiekti pavojingą medžiagą nuvertinimas ir žinių apie vaikams pavojingas medžiagas nepakankamumas, pvz., maisto papildai. Mažiems vaikams, kitaip nei paaugliams ir suaugusiems, vaistai dozuojami atsižvelgiant ị kūno masę arba amžių. Nors netinkamas vaistų dozavimas sudaro tik nedidelę apsinuodijimų dalį šioje amžiaus grupèje, net nedidelis vaistinès medžiagos perdozavimas gali lemti ūmų sveikatos būklès sutrikimą [12]. Dauguma 6-12 metų vaikų apsinuodijimų siejami su netyčinėmis vaistų dozavimo klaidomis (2 lentelè). Šios amžiaus

1 lentelè. Amžiaus grupèse būdingi apsinuodijimai.

+ labai retai, ++ retai, +++ dažnai, ++++ labai dažnai

\begin{tabular}{|c|c|c|c|c|c|c|c|}
\hline \multirow[b]{2}{*}{$\begin{array}{l}\text { Amžiaus } \\
\text { grupé }\end{array}$} & \multirow{2}{*}{$\begin{array}{c}\text { Namų } \\
\text { apyvokos } \\
\text { produktai, } \\
\text { kosmetika }\end{array}$} & \multicolumn{4}{|c|}{ Vaistai } & \multirow{2}{*}{$\begin{array}{c}\text { CO } \\
\text { ir kt. } \\
\text { dujos }\end{array}$} & \multirow{2}{*}{$\begin{array}{r}\text { Alko- } \\
\text { holis, } \\
\text { narko- } \\
\text { tikai }\end{array}$} \\
\hline & & $\begin{array}{l}\text { anal- } \\
\text { getikai }\end{array}$ & $\begin{array}{c}\text { psicho- } \\
\text { tro - } \\
\text { piniai }\end{array}$ & $\begin{array}{l}\text { kvėpa- } \\
\text { vimo } \\
\text { sistemos }\end{array}$ & $\begin{array}{c}\text { anti- } \\
\text { bioti- } \\
\text { kai }\end{array}$ & & \\
\hline $0-5 \mathrm{~m}$. & ++++ & +++ & +++ & ++ & +++ & ++ & + \\
\hline 6-12 m. & ++ & +++ & +++ & +++ & ++ & +++ & ++ \\
\hline $13-18 \mathrm{~m}$. & + & ++ & ++ & + & + & ++ & ++++ \\
\hline
\end{tabular}

2 lentelè. Vaikų netyčinio apsinuodijimo aplinkybès.

*Nesteroidiniai vaistai nuo uždegimo

\section{Netyčinis apsinuodijimas}

1. Dauguma pacientų iki 12 metų

2. Apsinuodijimo aplinkybès: aplinkos tyrinèjimas

netinkamos potencialių toksinų laikymo sąlygos

tèvai netaisyklingai dozuoja vaikams skirtus vaistus

3. Apsinuodijama viena medžiaga

4. Dažniausios medžiagos: kosmetikos ir higienos produktai, namų apyvokos produktai ir buitiniai chemikalai

5. Vaistinès medžiagos: dozavimo klaidos (NVNU*, antibiotikai), netinkamai lai komi suaugusiujų vaistai (psichotropiniai, širdies-kraujagyslių sistemą, kvėpavimo sistemą veikiantys vaistai)

3 lentelè. Vaikų tyčinio apsinuodijimo aplinkybės.

*Nesteroidiniai vaistai nuo uždegimo

\section{Tyčiniai apsinuodijimai}

1. Dauguma pacientų nuo 12 metų

2. Apsinuodijimo aplinkybès:

laisvalaikio leidimo būdas suicidiniai tikslai

3. Apsinuodijama keliomis medžiagomis. Dažnai viena iš medžiagų - etanolis

4. Laisvalaikio leidimo metu apsinuodijama nelegaliomis psichotropinèmis narkotinėmis medžiagomis

5. Suicidiniais tikslais - vaistinès medžiagos: NVNU* (paracetamolis), psichotropiniai vaistai grupès pacientai sudaro tik 5-9 proc., todèl atskirų studijų, išsamiau nagrinejjančių tendencijas šioje grupeje, yra nedaug $[5,11,13]$. Pastarųų kelerių metų duomenimis, stebima tendencija, jog vis dažniau nuodingosios medžiagos ir vaistai pasirenkami žalojimosi tikslais. Šis pakilimas siejamas su padidejjusiu naudojimusi internetu bei netinkamu viešujų asmenų informacijos skleidimu. Antrasis bimodalinio pasiskirstymo pikas būdingas vyresniems kaip 13 metų paaugliams. Studijų duomenimis, šiai amžiaus grupei būdingos labiausiai ị suaugusiujų panašios tyčinès apsinuodijimo aplinkybès: apsinuodijimas suicidiniais tikslais, piktnaudžiavimas tam tikromis medžiagomis eksperimentiniais tikslais, pvz: alkoholiu, narkotikais (3 lentelè). Paaugliai jau žino galimas savo elgesio pasekmes, tačiau formuojantis asmenybei, sunkumai mokykloje ar šeimoje, bet koks bendraamžių ar aplinkos (tėvai, vieši žmonès, televizija, internetas) spaudimas skatina neatsakingą elgesị. Berniukai linkę dažniau vartoti alkoholị ir ịvairias narkotines medžiagas kaip laisvalaikio praleidimo būdą, kuris neretai baigiasi apsinuodijimu ir gydymu VSPS $[14,15]$. Šios amžiaus grupès mergaitès dažniau linkusios perdozuoti vaistus suicidiniais tikslais [7,16,17]. Šiam tikslui dažniausiai pasirenkamas paracetamolis [13].

İvertinus pacientų būklę vaikų skubiosios pagalbos skyriuje, beveik $2 / 3$ pacientų buvo taikyta iki 24 val. stebejjimo paslauga [8,13,18,19], o 1,5-4,3 proc. apsinuodijusių prireikè intensyviojo gydymo, todèl pacientai buvo perkelti ị vaikų reanimacijos skyrių $[1,7,8,10,13]$. Apsinuodijimu gydymui VSPS ir vaikų reanimacijoje buvo taikomi šie metodai: aktyvinta anglis, priešnuodis arba skrandžio plovimas. Skrandžio plovimą, kaip gydymo būdą, analizuotose studijose naudojo dažniausiai iki 41,3 proc. atvejų, o aktyvinta anglis buvo pasirinkta tik mažiau nei trečdaliui pacientų $[1,8,13,19]$. Apsinuodijusiems paracetamoliu bei organiniais fosfatais buvo skiriamas gydymas žinomais priešnuodžiais, šis būdas sudarè 2-7,7 procento $[8,10,13]$.

\section{Išvados}

1. Tiriant apsinuodijimų epidemiologiją, vaiku populiacijoje stebimas dvigubas pikas, priklausomas nuo amžiaus: jaunesnių nei 5 ir vyresnių nei 13 metų amžiaus grupèse. 
2. Pirmojo piko metu didžioji dalis atvejų yra netyčiniai. Antrojo piko metu dažnesni tyčiniai apsinuodijimai laisvalaikio metu arba savižudybès tikslais.

3. Dažniausios apsinuodijimų priežastys iki 12 metų amžiaus grupèje yra dèl namuose vartojamų produktų, kosmetikos ir vaistinių preparatų pavartojimo.

4. Vyresnių kaip 12 metų vaikų apsinuodijimų etiologija panašesnè ị suaugusiujų. Vyresni berniukai dažniau apsinuodija alkoholiu, o mergaitès - vaistais, ypač paracetamoliu.

5. Skubiosios pagalbos skyriuje gydymas taikomas daugiau nei $2 / 3$ pacientų. Pagrindiniai metodai - skrandžio plovimas ir aktyvinta anglis.

\section{Literatūra}

1. Lee J, Fan NC, Yao TC, Hsia SH, Lee EP, Huang JL, et al. Clinical spectrum of acute poisoning in children admitted to the pediatric emergency department. Pediatr Neonatol 2019;60(1):59-67. https://doi.org/10.1016/j.pedneo.2018.04.001

2. Sebeščiuk D, Šurkienė G, Gruzdytė L. Lietuvos vaikų neinfekcinès kilmès apsinuodijimo atvejų 2012-2017 m. laikotarpiu analizè. Visuomenès sveikata, 2019;4(87):87-95.

3. WHO. Children and poisoning. http://www.who.int/violence_injury_prevention/child/en/

4. Mintegi S, Azkunaga B, Prego J, Qureshi N, Dalziel SR, AranaArri E, et al. International epidemiological differences in acute poisonings in pediatric emergency departments. Pediatr Emerg Care 2019;35(1):50-7. https://doi.org/10.1097/PEC.0000000000001031

5. Berta GN, Di Scipio F, Bosetti FM, Mognetti B, Romano F, et al. Childhood acute poisoning in the Italian North-West area: a six-year retrospective study. Ital J Pediatr 2020;46(1):83. https://doi.org/10.1186/s13052-020-00845-0

6. Ulseth ET, Freuchen A, Köpp UMS. Acute poisoning among children and adolescents in southern Norway. Tidsskr Nor Laegeforen 2019;139(13):1-8.

7. Santiago P, Bilbao N, Martinez-Indart L, Mintegi S, Azkunaga B. Epidemiology of acute pediatric poisonings in Spain: a prospective multicenter study from the Spanish society of pediatric emergency medicine. Eur J Emerg Med 2020;284-9. https://doi.org/10.1097/MEJ.0000000000000661

8. Gokalp G. Evaluation of poisoning cases admitted to pediatric emergency department. Int J Pediatr Adolesc Med 2019;6(3). https://doi.org/10.1016/j.ijpam.2019.07.004

9. Katic K, Stojadinovic A, Mijatovic V, Grujic M. Acute poisoning in children and adolescents hospitalized at the institute of child and youth health care of Vojvodina between 2015-2017. Med Pregl Rev 2019;72(7-8). https://doi.org/10.2298/MPNS1908209K

10. Nistor N, Frasinariu OE, Rugina A, Ciomaga IM, Jitareanu C, Ştreanga V. Epidemiological study on accidental poisonings in children from northeast Romania. Medicine (Baltimore) 2018;97(29):e11469.
https://doi.org/10.1097/MD.0000000000011469

11. Lee VR, Connolly M, Calello DP. Pediatric poisoning by ingestion: developmental overview and synopsis of national trends. Pediatr Ann 2017;46(12):e443-8.

https:/doi.org/10.3928/19382359-20171121-01

12. Koh SH, Tan KHB, Ganapathy S. Epidemiology of paediatric poisoning presenting to a children's emergency department in Singapore over a five-year period. Singapore Med J 2018;59(5). https://doi.org/10.11622/smedj.2018053

13. Boban IV, Vrca A, Saraga M. Changing pattern of acute alcohol intoxications in children. Med Sci Monit 2018;24.

https://doi.org/10.12659/MSM.908841

14. Pawłowska-Kamieniak A, Mroczkowska-Juchkiewicz A, Kominek K, Krawiec P, Mełges B, Pac-Kożuchowska E. Alcohol intoxication among adolescents and children in urban and rural environments - a retrospective analysis. Ann Agric Environ Med 2018;25(1).

https://doi.org/10.5604/12321966.1228397

15. Güngörer V, Y1ldırım NK. Evaluation of intoxicated patients hospitalized in a newly-opened level two pediatric intensive care unit. Turk Pediatr Ars 2016;51(1).

https://doi.org/10.5152/TurkPediatriArs.2016.2898

16. Chefirat B, Zergui A, Rahmani C, Belmessabih MN, Rezkkallah $\mathrm{H}$. Acute paracetamol poisonings received at the Oran university hospital. Toxicol Reports 2020;7.

https://doi.org/10.1016/j.toxrep.2020.08.025

17. Pawłowicz U, Wasilewska A, Olańnski W, Stefanowicz M. Epidemiological study of acute poisoning in children: a 5-year retrospective study in the paediatric university hospital in Białystok, Poland. Emerg Med J 2013;30(9).

https://doi.org/10.1136/emermed-2012-201376

18. Sahin S, Carman KB, Dinleyici EC. Acute poisoning in children; data of a pediatric emergency unit. Iran J Pediatr 2011;21(4).

\section{COMMON POISONINGS IN PEDIATRICS: A LITERATURE REVIEW}

D. Bartkus, R. Benešiūnaitè, L. Jankauskaitè

Keywords: children, intoxication, poisoning, epidemiology.

Summary

This work aimed to evaluate and analyze data from the scientific literature on the epidemiology of pediatric intoxications. The main topics of discussion were the prevailing toxic substances, the reasoning for poisoning, and the outcomes. All of the selected articles used for the analysis were full text. Based on the results, we can conclude that, for children aged below 12 years old, the most characteristic toxins are from various household items and that the accident happens unintentionally. Adolescents aged over 12 years old usually experience deliberate poisonings during leisure time or after a suicidal attempt. The most commonly used substances are ethanol and psychotropic drugs. The majority of patients admitted to the pediatric emergency department receive a non-specific antitoxic treatment - activated charcoal, gastric lavage.

Correspondence to: dovydas.bartkus@stud.lsmu.lt

Gauta 2021-04-26 